\title{
PERENCANAAN SCHEDULING DAN RESCHEDULING DENGAN METODE HEURISTIC SPT GUNA MEMINIMUMKAN MEAN TARDINESS DAN MAKESPAN
}

\section{Eti Kristinawati ${ }^{1}$}

\begin{abstract}
To complete customer's demand so company must make a plan with using production schedule. Some difficulties usually happen in shop floor level is a new job which is put in a production schedule that have arranged before. So that the old production schedule have to revised by reschedulling. The procedure that be used to schedule the real time production consist of $\mathrm{n}$ job $\mathrm{m}$ machine is algoritm of Hueristik Dispatching Rule Shorted Processing Time (SPT) method to minimize mean tardiness and makespan.

Implementing the chosen method to scheduling dan rescheduling because of additional job, so we can get production timet 49,13 hours or $9,69 \%$ off in October 2001 and overall efficiency about Rp. 1.812.791,10. Based on rescheduling with SPT priority after additional job in October 2001 can get production time about 49,15 hours or $9,18 \%$ of with overall efficiency about Rp. $1.812 .791,10$
\end{abstract}

Key Words : Production System, Schedulling and Reschedulling SPT, Makespan.

\section{PENDAHULUAN}

Saat ini produsen lebih dituntut untuk membuat produk yang sesuai dengan kebutuhan konsumen (customer needs) yang terdiri dari kualitas yang tinggi (High Quality), harga yang murah (Minimasi Cost) dan pengiriman tepat waktu (Delivery Time). Penjadualan produksi merupakan aspek yang penting dalam lingkungan industri manufaktur, terutama yang bersifat job shop. Penjadualan yang baik selalu berusaha untuk meningkatkan utilitas sumber daya yang ada, seperti mesin - mesin perkakas, tenaga kerja manusia, maupun fasilitas yang diinginkan, baik dari segi waktu maupun ongkos.

PT. Aneka Mesin Malang merupakan industri yang memproduksi beberapa jenis mesin, dimana scheduling dan rescheduling dalam proses produksinya tidak direncanakan terlebih dahulu Pada kegiatan proses produksi seringkali mengalami perubahan penjadualan karena adanya job sisipan. Dengan melihat kondisi di atas, maka perlu dilakukan suatu langkah untuk mengantisipasi permasalahan tersebut dengan merencanakan penjadualan dan penjadualan ulang yang optimal sehingga dapat meminimumkan mean tardiness dan makespan.

\section{TINJAUAN PUSTAKA}

\section{PENGUKURAN KERJA}

Pengukuran kerja merupakan suatu metode penetapan keseimbangan antara kegiatan manusia yang dikontribusikan dengan unit produk yang dihasilkan. Teknik atau metode pengukuran waktu kerja secara garis besar dapat dibedakan menjadi dua bagian, yaitu :

")Dosen Jurusan Teknik Industri Fakultas Teknik Universitas Muhammadiah Malang 
1. Pengukuran waktu kerja secara langsung (work sampling, stop watch time study)

2. Pengukuran waktu kerja secara tidak langsung (regresi linier, pre determined time study)

\section{Penetapan Jumlah Siklus Kerja Yang} Harus Diamati

Penyimpangan standart dinyatakan dalam tanda sigma $(\delta)$ yang dinyatakan dengan formula sebagai berikut :

$$
\delta=\sqrt{\frac{\left(\mathrm{X}_{1}-\overline{\mathrm{X}}\right)^{2}+\left(\mathrm{X}_{2}-\overline{\mathrm{X}}\right)^{2}+\ldots+\left(\mathrm{X}_{n}-\overline{\mathrm{X}}\right)^{2}}{\mathrm{~N}}}
$$

(Sumber : Sritomo W., Ergonomi, Studi Gerak dan Waktu, 1995, Hal.188)

Di mana:

$\mathrm{X}_{\mathrm{i}}=$ Data waktu yang dibaca oleh stop watch untuk tiap-tiap individu pengamatan $\bar{X}=$ Harga rata-rata dari semua data yang terbaca stop watch per elemen kerja $\Sigma \mathrm{X}_{i}=\Sigma$ semua data waktu yang diamati

Untuk menetapkan beberapa jumlah observasi yang seharusnya dibuat $\left(\mathrm{N}^{1}\right)$ dengan tingkat kepercayaan $95 \%$ dan derajad ketelitian $5 \%$ dari waktu yang diukur maka persamaannya sebagai berikut:

$$
\mathrm{N}^{\prime}=\left[\frac{\frac{k}{s} \sqrt{\mathrm{N} \Sigma\left(\mathrm{X}_{i}\right)^{2}-\left(\Sigma \mathrm{X}_{i}\right)^{2}}}{\Sigma \mathrm{X}_{i}}\right]^{2}
$$

(Sumber : Sritomo W., Ergonomi, Studi Gerak dan Waktu, 1995, Hal.189)

Dimana:

$\mathrm{N}^{1}=$ Banyaknya pengamatan yang harus dilakukan

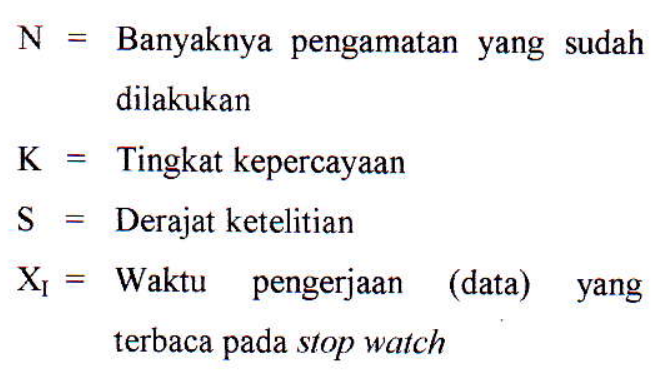

\section{Uji Keseragaman Data}

Adapun formula yang dipakai dengan derajad ketelitian 95\% adalah sebagai berikut:

$$
\begin{aligned}
\mathrm{BKA} & =\overline{\overline{\mathrm{X}}}+2 \mathrm{SD} \\
\mathrm{BKB} & =\overline{\overline{\mathrm{X}}}-2 \mathrm{SD}
\end{aligned}
$$

(Sumber : Sritomo W., Ergonomi, Studi Gerak dan Waktu, 1995, Hal.20I)

Dimana:

$$
\begin{aligned}
\overline{\mathrm{X}}= & \text { Harga rata-rata waktu } \\
& \text { pengukuran } \\
\mathrm{BKA}= & \text { Batas kontrol atas } \\
\mathrm{BKB}= & \text { Batas kontrol bawah } \\
\mathrm{X}_{\mathrm{i}=} & \text { Waktu pengamatan ke-i }(\mathrm{i}=1, \\
& 2,3 \ldots \mathrm{n}) \\
\mathrm{n}= & \text { Banyaknya pengamatan yang } \\
& \text { dilakukan }
\end{aligned}
$$

\section{Penentuan Waktu Normal}

Waktu Normal $=$ Rata-rata waktu pengamatan $x$ PR

(Sumber: Sritomo W., Study Gerak dan Waktu, 1995, Hal: 207) 


\section{Penentuan Waktu Baku}

Waktubaku $=$ Normaltime $\times \frac{100 \%}{100 \%-\% \text { allowance }}$

(Sumber: Sritomo W., Study Gerak dan

Waktu, 1995, Hal: 210)

\section{PENJADUALAN PRODUKSI}

"Penjadualan produksi didefinisikan sebagai proses pengalokasian sumber daya produksi (Mesin dan operator), kapan mulai proses, kapan selesai operasi untuk mengerjakan sejumlah job atau menjalankan sekumpulan tugas dalam jangka waktu tertentu".

(Kenneth R. Baker, 1984, hal.30)

\section{Tujuan Penjadualan}

Tujuan utama dalam proses penjadualan adalah meningkatkan penggunaan sumber daya (peningkatan utilitas). Tjuan yang lainnya antara lain :

1. Meminimumkan makespan.

2. Untuk mengurangi work in proses (wip)

3. Penentuan due date

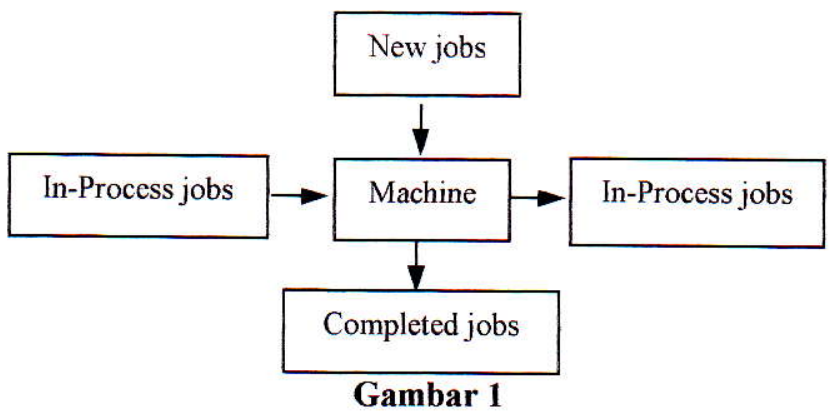

\section{Kerja pada mesin untuk job shop}

Sumber: John Wiley Sons, Introduction to sequencing and scheduling, 1974.

Persoalan job shop biasanya membutuhkan matrik waktu proses. Dan matrik routing Menunjukkan urutan mesin untuk mengerjakan beberapa operasi dari suatu jobs, seperti pada gambar berikut:

\section{ProsessingTime}

\begin{tabular}{|l|l|l|l|}
\hline Operasi & 1 & 2 & 3 \\
\hline Job 1 & 4 & 3 & 2 \\
\hline Job 2 & 1 & 4 & 4 \\
\hline Job 3 & 3 & 2 & 3 \\
\hline Job 4 & 3 & 3 & 1 \\
\hline
\end{tabular}

Gambar 2

Tabulasi data waktu proses dan Routing

Sumber: Introduction to sequencing and scheduling, John Wiley Sons, 1974
Teknik pembuatan algoritma heuristik dengan priority dispatching

- Step 1 : Pada saat $\mathrm{t}=0$, Pst kosong mula-mula St berisi semua operasi dengan tidak ada operasi pendahulunya.

- Step 2 : Tentukan $\mathrm{T}^{*}=\min \mathrm{j} \in \mathrm{St}$ (Tj) dan mesin $\mathrm{m}^{*}$ di mana $\mathrm{T}^{*}$ dapat direalisasikan.

- Step 3 : Untuk masing-masing operasi $j \in \mathrm{St}$ membutuhkan mesinmesin $\mathrm{m}^{*}$ dan untuk $\mathrm{Tj}=\mathrm{T}^{*}$, hitung prioritas indeks sesuai dengan aturan prioritas yang dipilih. Pst +1 untuk tahap berikutnya. 
- Step 4 : Untuk parsial schedule yang baru Pst +1 yang terbentuk pada step 3, ubah data set sebagai berikut:

a. Alihkan operasi j dari St.

b. Bentuk St +1 dengan menambah pengikut langsung dari operasi $\mathrm{j}$ ke St.

c. Naikkan t dengan satu.

- Step 5 : Kembali ke step 2 untuk Pst +1 yang terbentuk pada step 3, lakukan cara ini sampai semua job dijadualkan.

\section{Penyusunan Algoritma Scheduling}

- Step 1 : Pada saat $\mathrm{t}=0 \quad(\mathrm{t}$ menunjukkan stage), isikan St dengan semua job tanpa job pendahulu. Dan pada saat ini Pst kosong.

- Step 2 : tentukan $\sigma^{*}=\min$ j St $(\sigma$ ) dan $\mathrm{m}^{*} \mathrm{di}$ mana $\sigma *$ dapat direalisasikan.

- Step 3 : Untuk masing-masing job j $\sum$ St yang membutuhkan mesin $\mathrm{m}^{*}$, pilih job yang memenuhi syarat $\mathrm{T}=$ $\sigma^{*}$.

- Step 4 : Untuk jadwal parsial yang baru Pst +1 , yang dibentuk pada step 3, perbaharui data set seperti di bawah ini:
a. Alihkan job j dari $\mathrm{St}$
b. Bentuk St +1 dengan menambahkan pengikut langsung dari job j ke St
c. Tambahkan $t$ dengan 1

- Step 5 : Kembali ke step 2 untuk Pst +1 yang telah dibentuk pada step 3 dan 4 sampai sebuah jadual komplit dapat dibuat.

- Step 6 : Hitung perfomansi.

- Step 7 : Apakah terjadi gangguan berupa job sisipan selama proses berlangsung.

7.a Jika ya, lakukan rescheduling

7.b Jika tidak, penjadualan berakhir pada step 5 .

\section{Penyusunan Algoritma Rescheduling}

- Step 1 : Lihat routing job yang akan disisipkan

- Step 2 : Pada titik waktu tersebut $\left(\mathrm{t}^{*}=\mathrm{t}\right.$ gangguan, masuknya job sisipan).

- Step 3 : Tentukan:

- $\quad$ Operasi ke-n dari job yang baru

- Mesin yang akan digunakan untuk melakukan proses

- Waktu prosesnya

- Step $4 \quad$ : Lihat mesin yang dituju Apakah mesin dalam keadaan menganggur atau tidak.

- Step 5 : Jika mesin menganggur

Lihat apakah ada job yang akan dikerjakan dalam selang waktu antara $t^{*}$ sampai dengan $t^{*}+1$ operasi ke-n job baru.

5.a.Jika tidak ada

Jadwalkan pada mesin dan waktu tersebut

5.b Jika ada

Mundurkan operasi job lama pada pada $\mathrm{t}=\mathrm{t}+$ loperasi ke- $\mathrm{n}$

Job baru, dan sesuaikan jadual operasi seluruh job agar tetap valid. 
- $\quad$ Step 6

Apakah

dugaan

dimundurkannya operasi job lama tersebut

6.a Jika tidak ada, Jadualkan pada mesin dan awaktu tersebut

6.b Jika ada, Kembalikan posisi job lama pada posisi semula dan kemudian,

- Mundurkan job baru tersebut

- kemudian kembali ke step 4

- Step 7 : Jika mesin tidak menganggur

Lihat selesainya job yang sedang dikerjakan, pada $t^{*}=t^{*}+$ tsisa operasi job lama.

Kemudian dilihat kembali apakah mesin dalam keadaan menganggur.

7.a Jika ya

Kemudian kembali ke step 5

7.b Jika tidak

Mundurkan operasi job lama pada:

$=\mathrm{t}^{*}+\mathrm{t}$ operasi ke-n job baru

dan selesaikan jadwal operasi seluruh job agar tetap valid.

- Step 8 : Apakah yang dimundurkan operasi job lama tersebut

8. J Jika tidak ada

Jadualkan pada mesin dan waktu tersebut.

8.b Jika ada

Kembalikan posisi job lama pada posisi semula

- Step 9 : Hitung perfomance hasil rescheduling

1. Makespan

2. Complation time masing-masing job
3. Utilitas tiap-tiap mesin

4. Jumlah job yang terlambat

5. Total waktu keterlambatan

\section{METODOLOGI PENELITIAN}

\section{Jenis Data yang Diperlukan}

Data yang diperlukan meliputi data profil dan sistem produksi perusahaan, data jenis produk, struktur produk, permintaan produk, jenis mesin, routing pengerjaan masing-masing job, waktu proses tiap operasi, proses produksi serta due date dari job-job tersebut.

\section{Tahapan Pengolahan Data}

Proses pengolahan data meliputi beberapa tahapan antara lain :

1. Perhitungan Waktu Standart

2. Menentukan matrik waktu standart (dalam satuan jam) pengerjaan suatu job pada masing-masing mesin.

3. Perhitungan penjadualan tiap job dengan algoritma non-delay aturan SPT.

4. Perhitungan penjadualan tiap mesin dengan algoritma non-delay aturan SPT.

5. Perhitungan penjadualan ulang tiap job dengan algoritma non-delay aturan SPT.

6. Perhitungan penjadualan ulang tiap mesin dengan algoritma non-delay aturan SPT. 


\section{HASIL DAN PEMBAHASAN}

Berdasarkan analisa yang dilakukan, maka diperoleh hasil sebagai berikut :

Pada job shop didiskripsikan sebagai triplet (i, j, k) yang menotasikan operasi ke-j dari job i pada mesin ke-k. Dari hasil scheduling tiap job dan tiap mesin kemudian dapat diketahui nilai dari kriteria performansi yang diinginkan, yaitu sebagai berikut:

Tabel 1

Performansi Scheduling pada Bulan Oktober dengan Proritas SPT

\begin{tabular}{|c|c|c|c|c|}
\hline Performansi & Scheduling & Due Date & Waktu Awal & Keterlambatan \\
\hline $\begin{array}{c}\text { Complation Time } \\
\text { Job } 1 \\
\text { Job } 2 \\
\text { Job } 3 \\
\text { Job } 4 \\
\text { Job } 5 \\
\text { Job } 6 \\
\text { Job } 7 \\
\text { Job } 8 \\
\text { Job } 9 \\
\text { Job } 10\end{array}$ & $\begin{array}{c}217.78 \\
13.18 \\
7.94 \\
457.73 \\
15.4 \\
7.16 \\
3.74 \\
208.62 \\
151.95 \\
9.77\end{array}$ & $\begin{array}{c}220 \\
15 \\
10 \\
490 \\
18 \\
10 \\
7 \\
217 \\
160 \\
13\end{array}$ & $\begin{array}{c}2.22 \\
1.82 \\
2.06 \\
32.27 \\
2.6 \\
2.84 \\
3.26 \\
8.38 \\
8.05 \\
3.23\end{array}$ & $\begin{array}{l}0 \\
0 \\
0 \\
0 \\
0 \\
0 \\
0 \\
0 \\
0 \\
0\end{array}$ \\
\hline Makespan & $457.73 \mathrm{jam}$ & & & \\
\hline Job Terlambat & 0 & & & \\
\hline MeanTardines & 0 & & & \\
\hline MeanEarliness & 6.673 jam & & & \\
\hline
\end{tabular}

* Makespan $(\mathrm{Cmax})=$ Maximum Complation Time $=457.73 \mathrm{jam}$

Jumlah job terlambat (NT) $=$ I (Ii Ci $>$ di) $=0$

* Rata-rata Keterlambatan (MT) =

$$
\begin{aligned}
& \frac{\sum i W i L i}{\sum i W i}= \\
& \frac{\left(C i-\sum j \cdot P i j\right)(C i-d i)}{\left(C i-\sum j \cdot P i j\right)}=0
\end{aligned}
$$

* Rata-rata permulaan $(\mathrm{ME})=\mathrm{di}-\mathrm{Pij} /$ jumlah job

Pada bulan Oktober Perusahaan mampu menyelesaikan job selama 68 hari. Dengan SPT, dilihat dari nilai makespan sebesar 457,73 jam maka job pada bulan oktober timenya pada awal bulan.

Hasil perhitungan Rescheduling dengan aturan SPT pada bulan Oktober 2001

Tabel 2

Jenis job sisipan

\begin{tabular}{|l|c|c|}
\hline Jenis Job sisipan & $\begin{array}{c}\text { Nomo } \\
\mathbf{r} \\
\text { job }\end{array}$ & $\begin{array}{c}\text { Jumlah job } \\
\text { sisipan per } \\
\text { unit }\end{array}$ \\
\hline Pondasi Mesin & 4 & 2 \\
\hline Poros Utama & 8 & 1 \\
\hline Tangki & 9 & 2 \\
\hline
\end{tabular}

Tabel 3

Routing Processing Time Job Sisipan sesuai $\Sigma$ job

\begin{tabular}{|c|c|c|c|c|c|}
\hline \multirow{2}{*}{$\begin{array}{c}\text { Jenis } \\
\text { job }\end{array}$} & \multicolumn{5}{|c|}{ Proses } \\
\cline { 2 - 6 } & $\mathbf{1}$ & $\mathbf{2}$ & $\mathbf{3}$ & $\mathbf{4}$ & $\mathbf{5}$ \\
\hline Job 4 & 6.23 & 12.46 & 15.78 & & \\
\hline Job 8 & 1.04 & 4.15 & 3.12 & & \\
\hline Job 9 & 0.10 & 2.10 & 2.08 & 2.31 & \\
\hline
\end{tabular}


Dengan menerapkan algoritma rescheduling Non-Delay, maka dapat dilihat penjadualan ulang untuk job sisipan sebagai berikut:

Tabel 4

Hasil Perhitungan Rescheduling Tiap Mesin dengan Adanya Job Sisipan

\begin{tabular}{|c|c|c|c|c|c|}
\hline $\begin{array}{c}\text { Nomor } \\
\text { Machine }\end{array}$ & Operation & Job & $\begin{array}{c}\text { Waktu } \\
\text { Proses }\end{array}$ & $\begin{array}{c}\text { Waktu } \\
\text { Mulai }\end{array}$ & $\begin{array}{c}\text { Waktu } \\
\text { Selesai }\end{array}$ \\
\hline 1 & 1 & 3 & 1.04 & 0 & 1.04 \\
1 & 1 & 7 & 1.05 & 1.04 & 2.09 \\
1 & 1 & 5 & 1.24 & 2.09 & 3.33 \\
1 & 1 & 10 & 1.26 & 3.33 & 4.59 \\
1 & 1 & 9 (baru) & 0.10 & 4.59 & 4.69 \\
1 & 1 & 9 & 1.28 & 4.69 & 5.97 \\
1 & 1 & 2 & 1.33 & 5.97 & 7.30 \\
1 & 1 & 1 & 26.17 & 7.30 & 33.47 \\
\hline 2 & 2 & 3 & 1.31 & 1.04 & 2.35 \\
\hline 3 & 2 & 7 & 0.78 & 2.09 & 2.87 \\
3 & 3 & 3 & 1.79 & 2.87 & 4.66 \\
3 & 2 & 5 & 5.39 & 4.66 & 10.05 \\
3 & 2 & 2 & 1.54 & 10.05 & 11.59 \\
3 & 2 & 9 (baru) & 2.10 & 11.59 & 13.69 \\
3 & 2 & 9 & 26.30 & 13.69 & 39.99 \\
\hline 4 & 2 & 6 & 4.92 & 0.78 & 5.70 \\
4 & 2 & 8 (baru) & 4.15 & 26.84 & 30.99 \\
4 & 2 & 8 & 103.85 & 30.99 & 134.84 \\
\hline 5 & 2 & 10 & 1.81 & 4.59 & 6.40 \\
5 & 3 & 6 & 0.76 & 6.40 & 7.16 \\
5 & 5 & 3 & 0.78 & 7.16 & 7.94 \\
5 & 3 & 5 & 5.35 & 10.05 & 15.40 \\
5 & 2 & 4 (baru) & 12.46 & 104.73 & 117.19 \\
5 & 2 & 4 & 155.69 & 117.19 & 272.88 \\
\hline 6 & 3 & 7 & 0.87 & 2.87 & 3.74 \\
6 & 4 & 9 (baru) & 2.31 & 125.27 & 127.58 \\
6 & 4 & 9 & 28.86 & 127.58 & 156.44 \\
6 & 4 & 1 & 42.84 & 175.04 & 217.88 \\
6 & 3 & 4 (baru) & 15.78 & 272.88 & 288.66 \\
6 & 3 & 4 & 197.31 & 288.66 & 485.97 \\
\hline 7 & 1 & 6 & 0.78 & 0 & 0.78 \\
7 & 1 & 8 (baru) & 1.04 & 0.78 & 1.82 \\
7 & 1 & 8 & 26.06 & 1.82 & 27.88 \\
7 & 1 & 4 (baru) & 6.23 & 27.88 & 34.11 \\
7 & 1 & 4 & 77.89 & 34.11 & 112 \\
\hline 8 & 3 & 2 & 1.59 & 11.59 & 13.18 \\
8 & 3 & 1 & 77.91 & 97.13 & 175.04 \\
\hline 9 & 4 & 3 & 1.55 & 4.66 & 6.11 \\
9 & 3 & 10 & 3.37 & 6.40 & 9.77 \\
9 & 2 & 1 & 63.66 & 33.47 & 97.13 \\
9 & 3 & 9 (baru) & 2.08 & 97.13 & 99.21 \\
9 & 3 & 9 & 26.06 & 99.21 & 125.27 \\
\hline 10 & 3 & 8 (baru) & 3.12 & 134.84 & 137.96 \\
10 & 3 & 8 & 77.93 & 137.96 & 215.89 \\
\hline
\end{tabular}

Setelah dilakukan iterasi antara job sisipan, proses dan mesin yang dibutuhkan, serta hasil perhitungan iterasi processing time, start time, sehingga didapatkan finish penjadualan job di atas, mulai dari job time (waktu selesai) suatu job. Seluruh 
pertama sampai dengan job kesepuluh, tidak mengalami keterlambatan (tidak melebihi due datenya) sekalipun ada job sisipan sebanyak 3 jenis job.

Tabel 5

Performansi Rescheduling pada Bulan Oktober dengan Proritas SPT

\begin{tabular}{|c|c|c|c|c|}
\hline Performansi & Scheduling & Due Date & Waktu Awal & Keterlambatan \\
\hline Complation Time & & & & \\
Job 1 & & & & \\
Job 2 & 217.78 & 220 & 2.22 & 0 \\
Job 3 & 13.18 & 15 & 1.82 & 0 \\
Job 4 & 7.94 & 10 & 2.06 & 0 \\
Job 5 & 485.97 & 490 & 4.03 & 0 \\
Job 6 & 15.4 & 18 & 2.6 & 0 \\
Job 7 & 7.16 & 10 & 2.84 & 0 \\
Job 8 & 3.74 & 7 & 3.26 & 0 \\
Job 9 & 215.89 & 217 & 1.11 & 0 \\
Job 10 & 156.44 & 160 & 3.56 & \\
& 9.77 & 13 & 3.23 & \\
\hline Makespan & 485.97 jam & & & \\
\hline Job Terlambat & 0 & & & \\
\hline MeanTardines & 0 & & & \\
\hline MeanEarliness & 2.673 jam & & & \\
\hline
\end{tabular}

Pada bulan Oktober Perusahaan mampu menyelesaikan job selama 71 hari. Dengan SPT, dilihat dari nilai makespan sebesar 485,97 jam maka job pada bulan Oktober dapat diselesaikan selama 65 hari dan start timenya pada awal bulan.

Tabel 6

Perbandingan Performansi Rescheduling pada Bulan Oktober dengan Proritas SPT

\begin{tabular}{|l|c|c|}
\hline \multicolumn{1}{|c|}{ Kriteria } & $\begin{array}{c}\text { Rescheduling } \\
\text { Aktual }\end{array}$ & $\begin{array}{c}\text { Rescheduling } \\
\text { SPT }\end{array}$ \\
\hline Makespan & 535.12 jam & 485.97 jam \\
\hline Job Terlambat & 3 job & 0 \\
\hline Mean Tardiness & 4,512 jam & 0 \\
\hline Mean Earliness & - & $2.673 \mathrm{jam}$ \\
\hline
\end{tabular}

Dengan melihat tabel hasil perhitungan perbandingan performansi di atas maka, perusahaan dapat menerima order (job baru atau sisipan) tersebut. Karena melihat performansi di atas, adanya job sisipan dalam penjadualan tidak begitu $\mathrm{b}$ berpengaruh atau tidak terjadi keterlambatan yang berarti.
Analisa perbandingan biaya penerapan penjadualan aktual perusahaan dengan prioritas $S P T$ pada bagian proses produksi bulan Oktober 2001

\section{Gaji Karyawan}

1. Kondisi awal (aktual perusahaan) $4 \times(67,58$ jam $) \times$ Rp. 14.500,- = Rp. 3.919.640,-- 
2. Setelah menggunakan penjadualan dengan prioritas $S P T$

$4 \times(61,03$ jam $) \times$ Rp. $14.500,-=$

Rp. 3.539.740,-

\section{$>$ Operasi Mesin}

1. Kondisi awal (aktual perusahaan)

Tabel 7

Biaya Operasi Mesin Aktual bulan Oktober ' 01

\begin{tabular}{|r|r|r|}
\hline $\begin{array}{r}\text { Jenis } \\
\text { Mesin }\end{array}$ & Biaya operasi mesin & $\begin{array}{r}\text { Total biaya } \\
(\mathbf{R p )}\end{array}$ \\
\hline Potong & $1 \times(67,58) \times \mathrm{Rp} .25 .058,-$ & $1.693 .419,64$ \\
\hline Vibro & $1 \times(67,58) \times \mathrm{Rp} .24 .413,-$ & $1.649 .830,54$ \\
\hline Pounch & $1 \times(67,58) \times \mathrm{Rp} .22 .981,-$ & $1.553 .055,98$ \\
\hline Bubut & $1 \times(67,58) \times \mathrm{Rp} .22 .340,-$ & $1.509 .737,20$ \\
\hline Bor & $1 \times(67,58) \times \mathrm{Rp} .22 .017,-$ & $1.487 .908,86$ \\
\hline Las & $1 \times(67,58) \times \mathrm{Rp} .23 .444,-$ & $1.584 .345,52$ \\
\hline $\begin{array}{r}\text { Gergaji } \\
\text { Listrik }\end{array}$ & $1 \times(67,58) \times \mathrm{Rp} .10 .469,-$ & $707.495,02$ \\
\hline Roll & $1 \times(67,58) \times$ Rp. 22.335,- & $1.509 .399,30$ \\
\hline Penekuk & $1 \times(67,58) \times \mathrm{Rp} .24 .251,-$ & \\
\hline Fraish & $1 \times(67,58) \times \mathrm{Rp} .21 .454,-$ & $1.449 .861,32$ \\
\hline
\end{tabular}

Total biaya operasi mesin pada kondisi awal adalah Rp. 14.783.935,96.

2. Setelah menggunakan penjadualan $S P T$

Tabel 8

Biaya Operasi Mesin SPT bulan Oktober ' 01

\begin{tabular}{|c|c|c|}
\hline $\begin{array}{l}\text { Jenis } \\
\text { Mesin }\end{array}$ & Biaya operasi mesin & $\begin{array}{c}\text { Total biaya } \\
\text { (Rp) }\end{array}$ \\
\hline Potong & $1 \times(61,03) \times$ Rp. $25.058,-$ & $1.529 .289,74$ \\
\hline Vibro & $1 \times(61,03) \times$ Rp. $24.413,-$ & 1. $489.925,39$ \\
\hline Pounch & ) x Rp. 22.981,- & 1.402 .5 \\
\hline Bubut & 3) x Rp. 22.340,- & 1. $363.410,20$ \\
\hline Bor & $1 \times(61,03) \times$ Rp. $22.017,-$ & 1. $343.697,51$ \\
\hline Las & $1 \times(61,03) \times$ Rp. $23.444,-$ & $1.430 .787,32$ \\
\hline $\begin{array}{l}\text { Gergaji } \\
\text { Listrik }\end{array}$ & $1 \times(61,03) \times$ Rp. $10.469,-$ & 638. 923,07 \\
\hline Roll & p. $22.335,-$ & 1. $363.105,05$ \\
\hline Peneku & & $1.480 .038,53$ \\
\hline Fraish & $1 \times(61,03) \times$ Rp. $21.454,-$ & 1. $309.337,62$ \\
\hline
\end{tabular}

Total biaya mesin untuk pembuatan produk adalah Rp. 13.351.044,86.

Total biaya operasi mesin dengan penjadualan yang ditetapkan perusahaan $\mathrm{Rp}$. 14.783.935,96. Sedangkan penjadualan SPT biaya

operasinya

sebesar

Rp.

13.351.044,86, sehingga dengan

penjadualan SPT menghemat biaya sebesar

Rp. 1.432.891,1.

\section{Analisa perbandingan biaya kondisi} aktual dan sesudah Rescheduling dengan prioritas $S P T$ setelah adanya job sisipan.

\section{$>$ Gaji karyawan}

1. Kondisi awal (aktual perusahaan) $4 \times(71,35$ jam $) \times \operatorname{Rp} .14 .500,-=$ Rp.4.138.300,-.

2. Setelah menggunakan penjadualan ulang $S P T$ $4 \times(64,79$ jam $) \times$ Rp. 14.500,- = Rp.3.758.400,-

\section{$>$ Operasi Mesin}

1. Kondisi awal (aktual perusahaan)

\section{Tabel 9 \\ Biaya Operasi Mesin Aktual bulan Oktober '01}

\begin{tabular}{|c|c|c|}
\hline $\begin{array}{c}\text { Jenis } \\
\text { Mesin }\end{array}$ & Biaya operasi mesin & $\begin{array}{c}\text { Total biaya } \\
\text { (Rp) }\end{array}$ \\
\hline Potong & $1 \times(71,35 \times$ Rp. $25.058,-$ & 1.787. 888,30 \\
\hline Vibro & $1 \times(71,35) \times$ Rp. $24.413,-$ & I. $741.867,55$ \\
\hline Pounch & $1 \times(71,35) \times$ Rp. $22.981,-$ & 1. $639.694,35$ \\
\hline Bubut & $1 \times(71,35) \times$ Rp. $22 \cdot 340,-$ & 1.593 .959 \\
\hline Bor & $1 \times(71,35) \times$ Rp. $22.017,-$ & 1. $570.912,95$ \\
\hline Las & $1 \times(71,35) \times$ Rp. $23.444,-$ & 1. $672.729,40$ \\
\hline $\begin{array}{l}\text { Gergaji } \\
\text { Listrik }\end{array}$ & $1 \times(71,35) \times$ Rp. $10.469,-$ & $746.963,15$ \\
\hline Roll & $1 \times(71,35) \times$ Rp. 22.335 ,- & 1. $593.602,25$ \\
\hline Penekuk & $1 \times(71,35) \times$ Rp. $24.251,-$ & 1. $730.308,85$ \\
\hline Fraish & $1 \times(71,35) \times$ Rp. $21.454,-$ & 1. $530.742,90$ \\
\hline
\end{tabular}

Total biaya operasi mesin pada kondisi setelah adanya job sisipan adalah $\mathrm{Rp}$. $15.608 .668,7$.

2. Setelah menggunakan penjadualan ulang $S P T$ 
Tabel 10

\section{Biaya Operasi Mesin SPT \\ bulan Oktober '01}

\begin{tabular}{|l|l|r|}
\hline $\begin{array}{c}\text { Jenis } \\
\text { Mesin }\end{array}$ & Biaya operasi mesin & $\begin{array}{c}\text { Total biaya } \\
(\mathbf{R p})\end{array}$ \\
\hline Potong & $1 \times(64,8) \times \mathrm{Rp} .25 .058,-$ & $1.623 .758,40$ \\
\hline Vibro & $1 \times(64,8) \times \mathrm{Rp} .24 .413,-$ & $1.581 .962,40$ \\
\hline Pounch & $1 \times(64,8) \times \mathrm{Rp} .22 .981,-$ & $1.489 .168,80$ \\
\hline Bubut & $1 \times(64,8) \times \mathrm{Rp} .22 .340,-$ & $1.447 .632,00$ \\
\hline Bor & $1 \times(64,8) \times \mathrm{Rp} .22 .017,-$ & $1.426 .701,60$ \\
\hline Las & $1 \times(64,8) \times \mathrm{Rp} .23 .444,-$ & $1.519 .171,20$ \\
\hline $\begin{array}{l}\text { Gergaji } \\
\text { Listrik }\end{array}$ & $1 \times(64,8) \times \mathrm{Rp} .10 .469,-$ & $6.783 .912,00$ \\
\hline Roll & $1 \times(64,8) \times \mathrm{Rp} .22 .335,-$ & $1.447 .308,00$ \\
\hline Penekuk & $1 \times(64,8) \times \mathrm{Rp} .24 .251,-$ & $1.571 .464,800$ \\
\hline Fraish & $1 \times(64,8) \times \mathrm{Rp} .21 .454,-$ & $1.390 .219,20$ \\
\hline
\end{tabular}

Total biaya operasi mesin pada kondisi setelah adanya job sisipan adalah $\mathrm{Rp}$. $14.175 .777,6$

Tabel 11

Perbandingan Biaya Rescheduling pada Bulan Oktober 2001

\begin{tabular}{|l|l|l|}
\hline Kriteria & \multicolumn{1}{|c|}{$\begin{array}{c}\text { Rescheduling } \\
\text { Aktual }\end{array}$} & $\begin{array}{c}\text { Rescheduling } \\
\text { SPT }\end{array}$ \\
\hline $\begin{array}{l}\text { Gaji } \\
\text { karyawan }\end{array}$ & Rp. $4.138 .300,-$ & Rp. 3.758 .400 \\
\hline $\begin{array}{l}\text { Operasi } \\
\text { mesin }\end{array}$ & Rp. $15.608 .668,7$ & Rp. 14.175.777,6 \\
\hline Total & Rp. 19.746.968,7 & Rp. 17.934.177,6 \\
\hline
\end{tabular}

Dari tabel perbandingan biaya di atas, penghematan biaya sebesar ( Rp. 19. 746. 968,7 - Rp. 17. 934 . 177,6.) = Rp. 1. 812. 791,1

\section{KESIMPULAN}

Berdasarkan analisa data yang telah dilakukan maka dapat diambil kesimpulan, bahwa:

1. Urutan proses operasi berdasarkan hasil penjadualan dengan metode
Hueristic Dispatching Rule SPT pada bulan Oktober 2001, job dapat diselesaikan selama 61 hari dengan jadual urutan proses operasinya sebagai berikut

311, 711, 511, 10 1, 911, 211, 111, $322,723,333,523,223,923,624,824$, $1025,635,355,535,425,736,946$, $146,436,617,817,417,238,138,349$, $1039,129,939,8310$.

2. Urutan proses operasi berdasarkan hasil penjadualan ulang dengan metode Hueristic Dispatching Rule SPT pada bulan Oktober 2001 dengan job sisipan yang datang pada minggu ke-2 adalah sebagai berikut :

311, 711, 511, 10 1, 911, 911 (Baru), $911,211,111,322,723,333,523,223$, 923, 923 (Baru), 923, 624, 824, 824 (Baru), 824, 10 25, 635, 355, 535, 425, 425 (Baru), 425, 736, 946, 946 (Baaru), 946, 146, 436, 436 (Baru), 436, 617, 817, 817 (Baru), 817, 417, 417 (Baru), $417,238,138,349,1039,129,939$, 939 (Baru), 939, 83 10, 8310 (Baru), 8310.

3. Perbandingan hasil penjadualan kondisi awal dengan penjadualan metode SPT periode Oktober 2001 adalah sebagai berikut : 
Tabel 12

Perbandingan Kriteria Performansi Scheduling dengan Metode SPT

\begin{tabular}{|l|l|l|}
\hline \multirow{2}{*}{ Kriteri nilai } & \multicolumn{2}{|c|}{ Oktober 2001 } \\
\cline { 2 - 3 } & $\begin{array}{c}\text { Kondisi } \\
\text { awal }\end{array}$ & Aturan SPT \\
\hline $\begin{array}{l}\text { Total Waktu penyelesaian } \\
\text { (jam/periode) }\end{array}$ & 506,86 & 457,73 \\
\hline $\begin{array}{l}\text { Total biaya Produksi (Rp/ } \\
\text { periode) }\end{array}$ & $\begin{array}{l}18.703 .575, \\
96\end{array}$ & $\begin{array}{l}16.890 .784 .8 \\
6\end{array}$ \\
\hline \multicolumn{1}{|c|}{ Tingkat effisiensi } & \multicolumn{2}{|c|}{ Oktober 2001 } \\
\hline $\begin{array}{l}\text { Waktu penyelesaian } \\
\text { (jam/periode) }\end{array}$ & $\begin{array}{l}49,13 \text { (6,55 hari) atau 9,69\% } \\
\text { dari waktu penyelesaian }\end{array}$ \\
\hline $\begin{array}{l}\text { Total biaya Produksi (Rp/ } \\
\text { periode) }\end{array}$ & \multicolumn{2}{|c|}{ 1.812.791, 1 } \\
\hline
\end{tabular}

4. Perbandingan hasil penjadualan sebelum dan sesudah rescheduling pada bulan Oktober dengan SPT adalah sebagai berikut:

\section{Tabel 13}

\section{Perbandingan kriteria performansi rescheduling dengan metode SPT}

\begin{tabular}{|l|c|c|c|}
\hline \multicolumn{1}{|c|}{ Kriteria } & $\begin{array}{c}\text { Rescheduling } \\
\text { Aktual }\end{array}$ & $\begin{array}{c}\text { Rescheduling } \\
\text { SPT }\end{array}$ & Selisih \\
\hline Makespan & 535.12 jam & 485.97 jam & 28.24 jam \\
\hline $\begin{array}{l}\text { Job yang } \\
\text { terlambat }\end{array}$ & 3 job & 0 & 0 \\
\hline $\begin{array}{l}\text { Mean } \\
\text { Tardiness }\end{array}$ & 4,512 jam & 0 & 0 \\
\hline Mean Earliness & 0 & 2,673 jam & 4 jam \\
\hline Biaya Total & Rp. $19.746 .968,70$ & Rp. $17.934 .177,60$ & $R p .1 .812 .791,10$ \\
\hline
\end{tabular}

\section{DAFTAR PUSTAKA}

Baker, Kenneth R., Sequensing Rules and

Due Date Assigment in A Job Shop,

Manajement Sceince, Vol. 30 n0. 9.

Dervitsiotis, Kostas N., 1994, Operation

Management, Mc., Graw Hill, Inc.

Elsayed, Elsayed A. and Thomas Bbaucher,

1985, Analysis and Control of

Production System, Prentice Hall

Inc., New Jersey.

Morton, Thomas E. and David W. Pentico,

1993, Heuristic Scheduling System,

John Wiley and Sons, New York.
Walpole, Ronsld and Raymond H. Myers, 1986, Ilmu Peluang dan Statistik untuk Insinyur dan Ilmuwan, ITB Bandung.

Wignjosoebroto, Sritomo, 1992, Study Gerak dan Waktu, Guna Widya, 